\title{
Violations of Comparative Method APPLICATION WITHIN INTERNET Discussions OF Fiction
}

\begin{abstract}
The article characterizes logical method of comparison as an object of scientific research i.e. definition of it has been given, the method's aims have been mentioned, classifications and types of comparison have been listed. An example of violation of the comparative method application in the Internet discussions devoted to fiction pieces analyses has been considered. The subject of the Internet discussion has been accusations of plagiarism and chauvinistic objections to the necessity of Russianspeaking literature translation into Ukrainian.

Purpose: The purpose of the article is to characterize comparative method as an object for the research. Based on specific sample material to analyze facts of manipulation with information through the violation of comparative method application within the Internet discussion.

Material and methods: Comparative method has been used in the article - two poems' texts (Samuil Marshak's poem "The Absentminded Fellow from Baseynaya Street" in Russian and Ivan Malkovych's poem "The Absentminded Fellow" in Ukrainian have been compared; the content of the Internet discussion comments has been compared as well. Content and formal features correspondence in terms of the "plagiarism", "free literary translation", "literary borrowing" concepts have been analyzed. Deductive method has been applied in the form of logical conclusion based on the integrity of the analyzed facts.

Results: Comparison of poems according to formal scheme of poetic piece and their analyses allowed refuting of plagiarism accusations and prove relation of Ivan Malkovych's poem to the category of literary borrowings - in this very case - to free translation. The article is an example-attempt of scientific well-grounded refutation of information manipulations during Internet discussions, whose aim is to activate negative emotions of average uncritical philistine being unaware of literary work and history of literature.
\end{abstract}


Conclusions: In the sphere of information security the comparative method is both a means of informational aggression (in case of violation of comparison rules application) and anti-manipulation means (if the comparison rules are followed).

KEYWORDS: comparative method; plagiarism; literary borrowing; free translation; information manipulations; chauvinism.

\section{INTRODUCTION}

Comparison is one of the main scientific research methods and people can't go without it in their everyday life. Cognition of the surrounding world mostly depends on the level of perfection in how one can apply this method, which TV advertising demonstrates in quite a vivid way and which has been considered by Stanisław Flejterski and Jan K. Solarz: "Is an Eskimo having two dogs rich or poor? You don't know, as you don't have anything to compare with" (Flejterski \& Solarz, 2015, p. 7).

Comparison has been the subject for the following scientific works: within general scientific methodology - the works of Jerzy Apanowicz, Marian Cieślarczyk; in the sciences on national security - the works of Józef Buczyński, Tadeusz Jemioło, Andrzej Dawidczyk (Jemioło \& Dawidczyk, 2008, p. 53), Tomasz Kacała (Kacała, 2012); within political science methods the comparative one has been considered by Radosław Żydok; in the context of comparative financial sphere - Stanisław Flejterski and Jan K. Solarz; in Comparative Law studies Roman A. Tokarczyk (Tokarczyk, 2008) and others.

With the society becoming more involved in computer network communication, transfer of scientific discussions to the Internet, practice of logical methods application also transfers to the area of information. With the development of science knowledge of research methods themselves develop as well - their use is every time becoming more and more professional and demanding in reference to special knowledge availability. At the same time, actual experience of information manipulations doesn't only disappear, but also increases, unfortunately, through the violation of logical research methods application - this is often the base for informational and psychological wars, which easily grasp the Internet. Comparative method is one of the most widely spread ways of information manipulations in Internet communication and also one the main means to reveal such manipulations. 
We can state that today Internet is overloaded with informational manipulations. Also, the number of works on their detection both by particular researchers and in specialized issues of scientific editions is increasing (see Fedor, 2015). Imran Awan reveals technology of how the Internet and social media become a virtual field to enhance extremist views - to produce hatred on the Internet (Awan, 2017). Tatiana BonchOsmolovskaya analyzes strategies of informational resistance in the struggle against Russia's state propaganda machine (Bonch-Osmolovskaya, 2015). Sofiia Sokolova illustrates an attempt to uncover the informational manipulation technology in Wikipedia (Sokolova, 2017). The researches of Olga Bogolyubova and others prove that psychopathy is a unique prognostic factor of being involved to harmful behavior on the Internet and Facebook and their users with certain dark personality features possess identifiable linguistic characteristics (Bogolyubova et al., 2018).

The goal of the following article is to analyze facts of information manipulation through violations of comparative method rules applications within Internet discussions on a specific example.

\section{Comparative Method as an OBject OF INVESTIGATION}

Comparison is understood as a process of thinking or logical method of research, whose aim is to identify similarities and discrepancies of the subject, phenomena, process through correlation with other objects, phenomena, processes (Cieślarczyk, 2006, p. 51). The comparative method is also called an analogy.

According to Jan K. Solarz, the subjects of comparison can be both quantitative and qualitative objects and even the methods themselves (Table 1). In general, the following can be compared (Flejterski \& Solarz, 2015, p. 15):

- objects of comparison,

- their properties, which can be compared,

- the comparative method itself,

- the comparative's method aim,

- results of comparison. 
Table 1.

Comparison of quantitative and qualitative cognition methods.

\begin{tabular}{|c|c|c|}
\hline Aspect of Comparison & Quantitative Methods & Qualitative Methods \\
\hline Goal & Measuring & Understanding \\
\hline Theory & Hypothesis Refutation & Theory Formation \\
\hline Data & Apt and Exact & Subjective \\
\hline Procedure & Exact and Organized & Chaotic and Non-Structured \\
\hline Sample & Large to Medium & Small \\
\hline Representativeness & Controlled and Obtainable & Absence of Representativeness \\
\hline Statistic credibility & High & Incompletely Controllable \\
\hline Cognitive Meaning & Often Law & Sometimes High \\
\hline
\end{tabular}

Source: (Flejterski \& Solarz, 2015, p. 18).

The goals of comparative method application, in Józef Buczyński’s opinion, are as follows:

1) to understand and interpret certain facts, events;

2) to hierarchize these phenomena;

3) to foresee quantitative and qualitative development of the phenomena in a perspective context;

4) to form relations between all phenomena consciously, rationally and systematically (Buczyński, 2011, p. 59).

Generalizing scientific sources on the topic we can define the following classifications and types of comparison:

1. According to the subject of comparison (Buczyński, 2011, p. 62):

1.1. Institutional comparison - is the choice of, for instance, similar objects.

1.2. Functional comparison - is the choice of similar functions.

2. According to the way of comparison:

2.1. Comparison of objects to each other.

2.2. Comparison of objects (parameters or facts) to socially accepted standards. For quantitative and qualitative comparison of objects 
with socially accepted standards Jerzy Apanowicz suggested the following scale of comparison (Apanowicz, 2002, pp. 26-27) (choice of the scale's level depends on the research's goal):

2.2.1. comparison to norms and standards peculiar for certain scientific discipline, organization or structure, i.e. theoretical and physical models of specific peculiarities and properties;

2.2.2. comparison to standards, which define desirable state and intensiveness of this phenomena or properties; to methods and principles of managerial procedures and other parameters.

3. According to comparison time period:

3.1. Synchronous comparison (from the Greek ovv - "in common" and

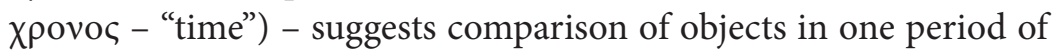
time development (horizontal cut view): on the contemporary stage or in certain historical period.

3.2. Diachronic comparison (from the Greek $\delta ı \alpha$ - "through", "throughout" and $\chi \rho \circ o v o \varsigma$ - "time") - comparison of objects which existed or exist under the same conditions in different historical periods; it is mostly applied according to historical sequence of these periods. According to Józef Buczyński, it is a manifestation of the so called descriptive (factual) function of the research process which allows revealing the state of system based on original platform. It means that comparison aims to find an answer to the question "How did it use to be and how is it now?” (Buczyński, 2011, pp. 58-59).

It is necessary to use comparative method carefully and attentively, keeping to the following key principles:

a) to compare similar, corresponding phenomena,

b) to detect not only similarities, but also differences,

c) to compare mostly essential properties (peculiarities) of the researched phenomena (Cieślarczyk, 2006, p. 51).

The comparative method is widely used in different scientific spheres and for some of them it is even the main one; the following spheres are traditionally mentioned (the list is not complete): 
- Comparative Philosophy - is a comparative study of philosophical traditions: schools, doctrines, systems etc.

- Comparative Literature - compares literary pieces belonging to literature of different nations as well as influences and dependence in literature;

- Comparative-Historical Linguistics (Genetic Linguistics, Comparative Linguistics) considers development of related languages and explains changes which have taken place in them. Jan Such, Małgorzata Szcześniak emphasize that with thehelp of this method differentlanguagesordifferent historical phenomena both existing and secondary are compared (Such \& Szcześniak, 2000, p. 15);

- Comparative Law considers similarities and discrepancies in law systems of certain states. In scientific literature there are Constitutional Law, Comparative Criminal law and others.

Stanisław Flejterski and Jan K. Solarz name such branches as: Comparative Finances, Comparative Research in State Policy, Comparative Political Studies, comparative research of social sciences and comparative research of cultures (Flejterski \& Solarz, 2015).

\section{THE SUBJECT OF THE INTERNET-DisCUSSION: Two Poems ANd One Plot}

Social networks have become a fruitful field for information manipulations. Use of short emotional remarks in the social networks promotes spreading of unproven manipulation schemes. In this article a poster named "The peak of patriotic decrepitude" from Facebook network spread by one of the users has been analyzed (Screenshot 1).

Gleb Lyashenko, the poster's author, presents two columns - a poem in Russian by the Soviet poet Samuil Marshak "The Absentminded Fellow from Baseynaya Street" (Marshak: Vot kakoy rasseyannyy) and its free Ukrainian translation, performed by Ivan Malkovych (Malkovych: Otakyy rozzyava). The author accompanies the poems supposed to be compared by his own comment: "The peak of patriotic decrepitude. Attention! It's not a joke. Poor Samuil Jakovlevich is turning over in his tomb". 
Screenshot 1.

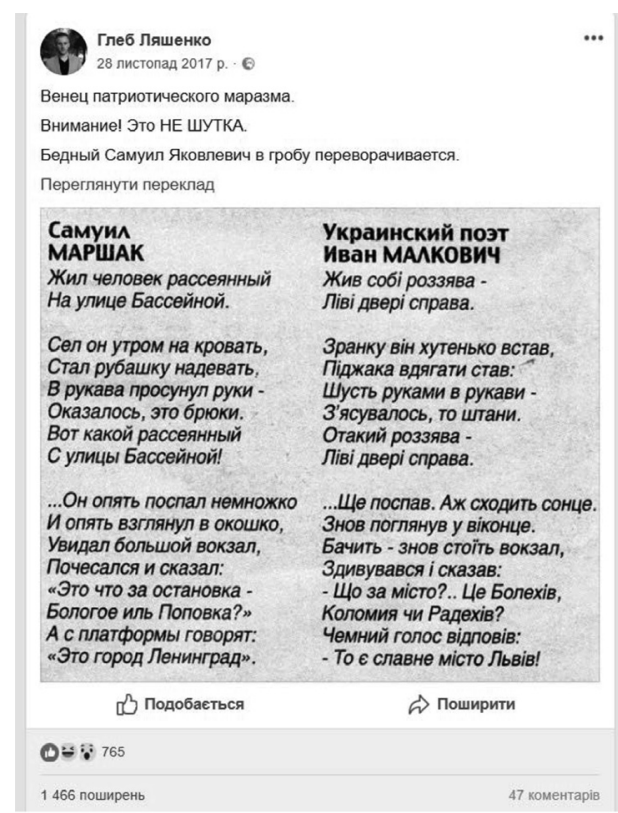

Source: (Lyashenko, 2017).

In his comments to the poster readers sharing the author's anti-Ukrainian temper resent plagiarism in different ways and speak up in quite humiliating way regarding the free translation's author and Ukrainian culture in general. Main claims can be formulated in the following way:

Ivan Malkovych's poem is a plagiarism,

neither this one, nor all other translations of Russian literature have no right to exist, as Russian has been and should be understandable for everybody - everyone should know it.

\section{Difference between Plagiarism and Literary BORROWING}

To find out weather Gleb Lyashenko applied comparative method to Samuil Marshak's “The Absentminded Fellow from Baseynaya Street” and Ivan Malkovych's “The Absentminded Fellow” correctly it's necessary, first of all, to define generally accepted terminology clearly. 
The main accusation is of Ivan Malkovych's plagiarism. That's why definition of "plagiarism" as a term is worth considering.

In national legal sphere there is the following definition of plagiarism. Ukrainian lawmaker in Article 50 of The Law of Ukraine "On Author's Right and Related Rights" provides the following definition of plagiarism: "plagiarism is promulgation (publication), completely or partly of someone's else work under the name of a person who isn't the author of this work" (Zakon Ukrayiny, 1993).

Let's give definition which is common in international scientific sphere. Committee on Publications Ethics (COPE), an international organization authoritative in the scientific field whose mission is to promote spreading best techniques of scientific publications ethics and which creates recommendationssamples for scientific publishing houses, considers plagiarism as involving texts fragments (large of small) and/or data of someone's else work without mentioning real author and presenting ones under the name of a person who is not their author (Wager, 2013). Besides, COPE doesn't even prove of selfplagiarism as well.

Immediately after the title "The Absentminded Fellow" the poem contains the following comment in all publications: "I. Malkovych after S. Marshak. Free translation from Russian". Consequently, we come to the conclusion that accusations of Ivan Malkovych of plagiarism are groundless, because this poem has never been published without reference to its original source.

Ivan Malkovych himself, telling story about composing the free translation informs, that he had been writing the poem for about 1-2 years, starting from about 1992 and when he was writing it, the name of Leningrad (the town was later renamed Saint Petersburg) mentioned in the original source disappeared. It was the very moment when Malkovych understood that he had to make a translation-travesty (Ivan Malkovych). As Oleksii Shevnin remarked wittily, “...we have no chance to translate Samuil Marshk's poem "There lived once such an absentminded fellow in the Baseynaya Street" into Ukrainian". Yet, our Ivan Malkovych has found corresponding variant, not literally precise one, but reflecting the poem's spirit: "Once there lived an absentminded fellow - left door to the right" (Shevnin, 2016).

Malkovych has always presented his poem as free translation i.e. "a poem, based on motives of other person's poetry with elements of versioning 
elements imitation, close to translation, but different due to lack of equivalence in rhythmic patterns" (Literaturoznavchyy slovnyk, 2007, p. 531). Ukrainian language dictionary explains Ukrainian term "to re-sing" (provide free translation) as a verb with figurative sense "to translate poems not being seriously concerned about exact equivalence to the original" (Perespivuvaty, 1975, p. 284). "Re-sung" compositions are one of the literary borrowing types, clear definition of which has been presented in a reference book on literary criticism:

Borrowings in literature are the use of already known motives, plots, images, ideas, artistic means and techniques from other folk, mythological or literary sources. ... To some extent, borrowings are actualized through free translations, stylization, application, parody, imitation namely through mimetic principle. If the author doesn't take the distance to the sample of his borrowing in account, if he doesn't transform it mentally in a creative way, doesn't transfer it into a new artistic quality, than it's about plagiarism and epigonism which discredit art, distort the sense of inter-literary relations. Literary borrowings are studied by theory of borrowing or the "theory of migratory plots"... (Literaturoznavchyy slovnyk, 2007, p. 276).

\section{COMPARISON OF THE POEMS ACCORDING TO FORMAL SCHEME OF POEM'S ANALYSES}

When comparing the poem of Samuil Marshak "The Absentminded Fellow from Baseynaya Street” (in Russian) and Ivan Malkovych's “The Absentminded Fellow" (in Ukrainian) according to formal scheme of analyses traditionally applied to poetry we see that both poems belong to literature for children genre, they are devoted to the topic of absentmindedness: the aim of each composition is to expose human's drawback with visible exaggeration. The main idea is to demonstrate using vivid example what an extreme absentmindedness may cause to a person. Main hero of both poems embodies lack of discipline and chaos.

According to the plot, in both texts the character first puts on clothes which aren't clothes, then goes to railway station where he stays in a detached carriage, thinking that he's traveling. Narration in each poem is performed from the third person. Such similarities of both texts could be enough for traditional translation. 
But Marshak wrote his poem in the first half of the $\mathrm{XX}^{\text {th }}$ century - in 1930, that's why it completely reflects geographic and material situation of that time, although it is still remaining extremely popular (despite outdated vocabulary and toponymy). From the pragmatic point of view, it would have been quite inappropriate to keep to geographic-material base when translating the poem as it wouldn't be understandable for children. That's why Malkovych transferred the events to contemporary Ukrainian circumstances - his hero lives in Lviv. While in Samuil Marshak's poem he intends to travel from Leningrad (now St. Petersburg) to Moscow. Due to such a "disguise" of the main hero Ivan Malkovych even called his free translation a travesty (Ivan Malkovych, 2014) (from Italian travestire - to "disguise" (Literaturoznavchyy slovnyk, 2007, p. 674)) - "type of humorous poetry, close to parody..." humorousness in travesties has been usually achieved by the fact that characters... have been transferred to the environment not peculiar to them..." (Travestiya, 1979, p. 220).

Scientist Maiia Hural has practically carried out an ordinary-scale data analyses based on comparison of original text and the free translation; she managed to distinguish and list lexemes and phrases-substitutes, grammatical substitutes, stylistic peculiarities of the free translation. As a result she summarizes that in Ivan Malkovych's free translation "one can't deal without compensatory techniques when translating complex units without their substitution by corresponding synonym, pronoun, periphrasis... translator often becomes a co-author of the text, but not its interpreter, he adds something from himself, something very national, Ukrainian, which encourages reader's respect..." (Hural, 2016, pp. 106-108).

So, comparative consideration of the literary pieces form the point of view of literary criticism proves that Ivan Malkovych's poem is a free translation, not a translation as it is stated in his every official publication.

\section{Comparative Method Application IN ON-Line Discussion}

At the same time, we can define that Gleb Lyashenko, the author of the post about Marshak and Malkovych poems comparison on Facebook, is a plagiarist himself as he doesn't mention neither real name of the author, who 
started comparing these two poems, nor the source where he has borrowed the comparison. As we managed to find out from the Internet sources, the author of the poems' comparison is Vladimir Kornilov, who calls himself a political scientist, journalist, publicist and TV presenter - this is a person with vivid anti-Ukrainian convictions, which he publicizes systematically particularly in his blog. S. Marshak and I. Malkovych's poems comparison was published on 06.25.2012 in "Blog of Vladimir Kornilov" (Kornilov, 2012), it was also accompanied by scornful statements addressed both to Ivan Malkovych and Ukrainian educational system which offers schoolchildren such "translations" for study. The content of the article discussion in comments can be summarized by words of one of the discussion participants aiming at Ukrainian opponents: "The very fact of existence of Your Russian poets talentless translations is an INSULT already!” (Screenshot 2). We may leave this manifestation of jingoism (chauvinism) in its traditional sense without any comment: as an aggressive form of nationalism, which reveals itself through propaganda of ideas of national exclusivity and priority; oppression of "smaller nations", which takes forms of, in particular, political oppression, cultural dominance, language assimilation or their combination etc. (Jingoism; Chauvinism; Yas, 2013; Toftul, 2014, p. 396).

\section{Screenshot 2.}

Source: (Aleksandr, 2013).

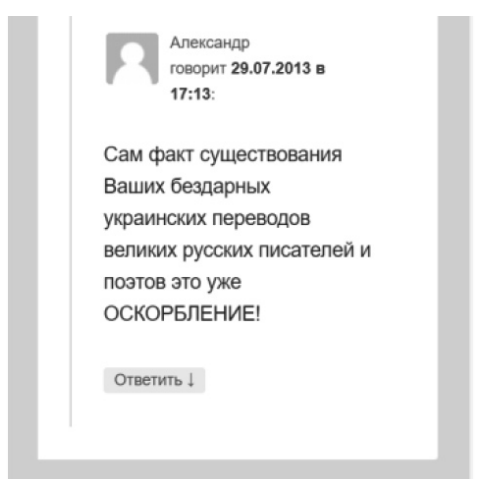

There is no doubt that the journalist and publicist (as Vladimir Kornilov calls himself) is familiar with conception of literary borrowings, free translations and translations - that is why a problem of refutations expediency arises in 
case when Kornilov's comparison aim is not to perform literary analyses, but is rather peformed for political manipulations. In the discussion, apart from Ukrainophobia supporters there were participants who tried to explain invalidity of accusations but their ideas have remained out of consideration. One of them having at last understood the real goal of Kornilov's article has summed up: "Only feeling pathological hatred for everything Ukrainian one's exaggerating opinions may result into such a delirium, similar to Your inventions" (Screenshot 3).

\section{Screenshot 3.}

Source: (Vladislav, 2012).

Владислав
говорит 27.06.2012 в 17:35.
С самой постановки «вопроса».
Впервые я услышал «переспів"
Малковича на аудио-диске,
который купил для сына.
Признаюсь - «поржал» от-души. И
сразу посмотрел - что это такое в
сопроводительной информации к
диску. Там была вся необходимая
информация для правильного
понимания. Я далёк от
«галичанської» культуры, но
признаю её существование. Только
испытывая патологическую
ненависть ко всему украинскому
можно высосать из пальца бред
подобный Вашим измышлениям
(он, кстати, уже является
предметом пристального изучения
на сайте duгоот.іп.иа). Причём Вы
так поставили вопрос, что и у меня,
восточного украинца, нет другой
оценки, кроме как: «...это говорит
враг...».

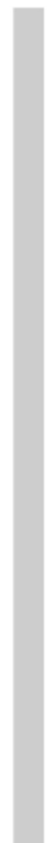

Coming back to the discussion devoted to Gleb Lyashenko's post on Facebook, we see that only three people have appeared to be aware of "artistic literary translation" and "free translation". They remind us that literary imitations are traditional for literature. A lot of examples can be given to this point. In particular, Ihor Buh claims, that Ivan Malkovych has never called himself an author and the poem is stated as free translation of S. Marshak 
from Russian everywhere. Instead, another poem by Samuil Marshak titled "Humpty Dumpty" (Marshak, Shaltay-boltay) is actually a literary translation of the English poem, which hasn't been stated in publications, the same is true for the original sources in other literary translations of Samuil Marshak (Screenshot 4).

\section{Screenshot 4 .}

Source: (Buh, 2017).

Irop Буг ути-пути ))

где указано что это перевод:

http://www.world-art.ru/lyric/lyric.php?id=4371 вот этого

Humpty Dumpty sat on a wall,

Humpty Dumpty had a great fall.

All the king's horses,

And all the king's men,

Couldn't put Humpty together again.

Самуил Маршак - Шалтай-болтай (о)

WORLD-ART.RU

Подобаеться - Переглянути переклад - 23 тиж.

In response to undeniable arguments of Ihor Buh his opponent Sergey Kurnosov just simply states: "It's too boring to stay with you" and quits the discussion (Screenshot 5).

\section{Screenshot 5.}

Irop Буг Сергей Курносов шта?

Где Малкович заявляп что это его стихотворение а не перевод?

Подобається : 23 тик.

6. Irop Eyr http://ukrclassic.com.ua/.../1508-ivan-malkovichotakij...

Іван Малкович - Отакий роззява

UKRCLASSIC.COM.UA

Подобаеться - 23 тиж.

(8) Irop Eyr http://mova.ga/.../819/otakyj-rozzyava-livi-dverisprava-2!

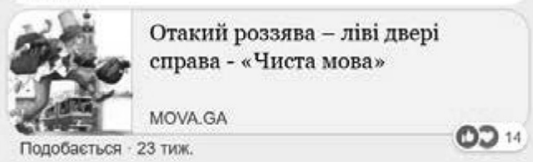

(3) Sergey Kurnosov Скучно с вами ))) адьёс амигос.. Подобаеться - 23 тиж.

Source: (Kurnosov, 2017). 
Among other examples of literary borrowings Facebook discussion participants give the following popular works:

- Ivan Krylov's fables (1769-1844), certain plots have been borrowed from Jean de La Fontaine's (1621-1695) fables (who, in his turn, borrowed them from Aesop (VI century B.C.), Phaedrus $\left(20^{\text {th }}\right.$ or $15^{\text {th }}$ year B.C. $-70^{\text {th }}$ year. A.D.) and Babrius (II century A.D.);

- "The Golden Key or the Adventures or Buratino" (1936) fairy tail's plot was borrowed by Aleksey Tolstoy from “The Adventures of Pinocchio" (1883) by Carlo Collodi;

- novel-fairy tail "The Wizard of the Emerald City" (1939) by Alexander Volkov is a converted version of L. Frank Baum's “The Wonderful Wizard of Oz" (1900).

But this didn't prevent other participants of the Facebook-discussion despite all remarks, from continuous scorning of Ukrainian language, culture and Ukrainians proper and with not the best vocabulary including wishes of death... such form of "dialogue" drives to conclusion, that the discussion's aim isn't search for truth - discussion is only an additional occasion to dishonor everything related to Ukraine.

What is interesting is that in both Internet-remarks (article of Vladimir Kornilov and Gleb Lyashenko's post) we observe the same tendencies. Vladimir Kornilov and Gleb Lyashenko's followers are aggressive and don't restrain themselves from Ukrainophobia-like expressions. Instead, their opponents call both the author of comparison and the author of the post either ignoramuses (Lukanov, 2017) or enemies (Yaskov, 2017).

\section{Discussion}

If analyze the theme of literary borrowings in the world literature through comparison of literary texts in different languages - a lot of plot "coincidences" can be found and very often without mentioning the author of the original source. In particular, Yuriy Vynnychuk, the writer, stresses peripheral nature of Russian cultural achievements when comparing to world literature. For example, Mikhail Bulgakov "borrowed many images and plot techniques" from the novel of Pierre Mac Orlan "Marguerite de 
la nuit" (1925) and novel of Alexandre Dumas “Joseph Balsamo” (1853). According to Y. Vynnychuk, "when reading Bulgakov an American will remember Mark Twain's “The Mysterious Stranger” (1898)... A Germanspeaking reader will notice plenty of reminiscences from the novel of Gustav Meyrink "Der Engel vom westlichen Fenster" and someone more well-read will be almost perplexed by amazing coincidence in "The Adventures of an adventurer, Hugo von Habenicht”, a classic of Hungarian literature Mór Jókai (1825-1904)... In short, there is a problem with Bulgakov. Eventually, the same can be observed with Pushkin, whom Frenchmen don't take into account, considering him a usual epigone of French poetry. Quite a lot of classical Pushkin's poetry, including “The Tatiana's letter" are free translations from French" (Vynnychuk, 2018).

Because of these conclusions, Russophiles this time rushed at Yuriy Vynnychuk. And again, replies to Vynnychuk contain no line of literary analyses or other of his words refutation - all articles-protests focus only on humiliation of personal or literary skills of Yuriy Vynnychuk (Na Ukraine..., 2018).

As we see, the world literature appreciators have a list of questions related to ethics of literary plots involvement by prominent Russian writers and poets, who didn't refer to the original sources of borrowed literary plots. But mentioning such facts in the Internet discussions always provoke flurry of indignation, often accompanied by non-normative vocabulary. Arguments have no sense - only emotions rule the game.

So, we see the situation when people ignorant in the field of literary studies axiomatically perceive authorship of Russian writers whose works are based on plots which have actually been borrowed. Instead, when the Ukrainian poet created a free translation of the Russian poem Russophile participants of the discussion accused the Ukrainian of plagiarism. Besides, in their opinion, Russian-speaking literary pieces should be read only in original - everyone should know Russian.

It is possible to explain aggression of pro-Russian internet-discussion participants to Ukrainian translations only by Russian chauvinism, whose main idea is reflected in a propagandist poster with the title: "In the matter of literature, Slavic-Russian language has indisputably supremacy to all European languages" (Foto 1). 
Foto 1.

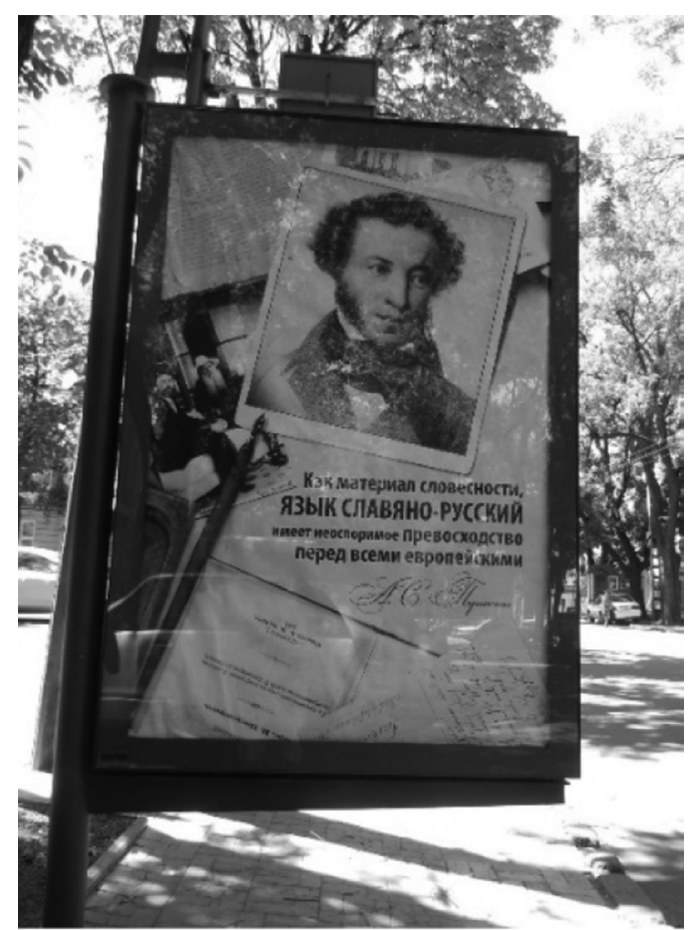

Source: (Kvach, 2013).

Radosław Żydok emphasizes that difficulties in comparative method application are stipulated by the necessity of correct choice of institutions for comparison (Żydok, 2008). As a well-aimed illustration of such correct choice for comparison which illustrates technology of information manipulating in mass media can be considered a post, published on Facebook under the title "Some Words on Information Presenting", where it is stated: "It's rust. Oxygen acetifies iron. We breathe in oxygen every day. If oxygen causes this to a chain, then just imagine what it does to your lungs. Let's share this information about danger from oxygen" (Screenshot 6). Violations of comparison rules are actual here - absolutely incommensurable phenomena have been compared: chemical influence of oxygen on iron and functions of living organism (breathing). The same principle is the base for comparison of Samuil Marshak's and Ivan Malkovych's poems. 
Screenshot 6.

Source: (Dubova, 2018).

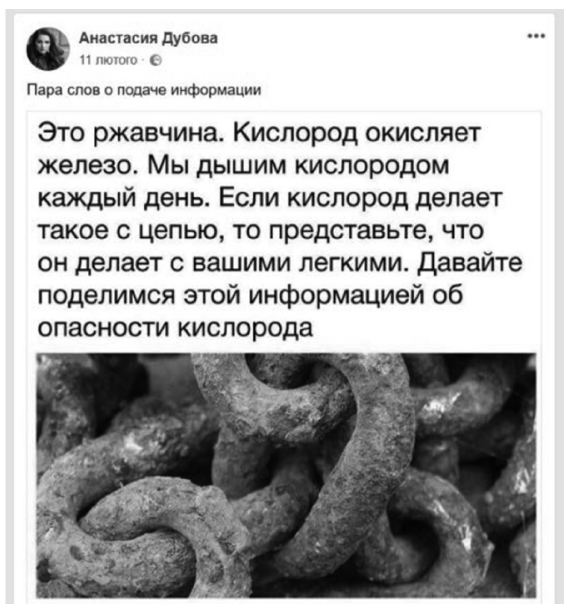

\section{Conclusions}

In the article the example of comparative method rules violations within Internet-discussions on literary works, Samuil Marshak's poem "The Absentminded Fellow" in Russian and Ivan Malkovych's poem "The Absentminded Fellow" in Ukrainian, has been considered. The subject of the Internet discussion has been accusations of Malkovych of plagiarism and refutations of the necessity to translate literature in Russian into Ukrainian.

In the following research logical method of comparison has been characterized as a research object - the definition has been given, comparative method goals have been listed, classifications and types of comparison have been outlined; an open list of scientific disciplines where comparative method is the main method of scientific research has been outlined.

In order to clarify correctness of comparative method application in the analyzed Internet discussion the definitions of such terms as "plagiarism", "literary borrowing" and "free translation" have been suggested. Comparison of the poems according to formal scheme of poetry analyzes which has been performed in the article as well as analyzes of the poems' relevance to given definitions allowed refutation of Ivan Malkovych's plagiarism and proving relation of Malkovych's poem to the category of literary borrowings, in this case, to examples of free translation. 
To sum up, the topic of the analyzed post on Facebook (as its source on the author's blog) belongs to comparative literature - comparison of analyzed poetry. The analyzed comparison in the article is pseudo-institutional as comparison objects aren't equivalent. The author of comparison resulted in gross violations of comparative method rules application as he's compared heterogeneous objects: he hasn't taken two independent author's works, but poem-original in Russian and its officially declared free literary translation in Ukrainian. According to time perspective, comparison is a diachronic procedure, as works representing evolution of fictional plot from one to another historical epoch have been compared.

Having got acquainted with texts and correspondence on the comparison's author, Vladimir Kornilov, personal blog we come to conclusion that the comparison's author can't be called incompetent in distinguishing concepts of "artistic borrowing", "borrowing" and "plagiarism" - i.e. taking into account powerful political-emotional impetus which his text bears we see manipulation of information directed to the incitement of readers' emotions, who don't perceive critically the information published in the networks.

The article is an example of scientifically-grounded refutation of information manipulations on the topic of literary works discussions. And because, as Tadeusz Jemioło and Andrzej Dawidczyk claim, comparative research is based on the statement that person's behavior is permanent under the same conditions despite the place and the time (Jemioło \& Dawidczyk, 2008, p. 53) - the author hopes, that this article will be an example for further refutations of other informational manipulations in texts discussing topics of fiction or other related spheres on the Internet.

We may conclude, that in the sphere of informational security the comparative method provides informational aggression both as a means of informational manipulations (in case of comparative method rules violations) and anti-manipulation means which allows manipulations refutation and revealing the truth (comparison with following all rules of the method's application).

Further comparative studies should be carried out in the direction, based on the thesis of Józef Buczyński about the fact that different people react to the same threat in different ways (Buczyński, 2011, p. 62) - reaction of 
different society layers to the same forms of information manipulations are still worth considering in a more detailed way.

\section{References:}

Apanowicz J. (2002). Metodologia ogólna. ISBN 83-910869-9-3. Gdynia: BERNARDINUM, 159 p. Retrieved 20.05.2018 from: https://wsaib.pl/images/files/E-Publikacje/MO.pdf

Awan I. (2017). Cyber-Extremism: Isis and the Power of Social Media. Society. ISSN: 0147-2011. April 2017, Vol. 54, Iss. 2, pp. 138-149. Publication: 15 March 2017. Retrieved 09.06.2018 from: https://link.springer.com/article /10.1007/s12115-017-0114-0. DOI: 10.1007/s12115-017-0114-0.

Bogolyubova O., Panicheva P., Tikhonov R., Ivanov V., Ledovaya Y. (2018). Dark personalities on Facebook: Harmful online behaviors and language. Computers in Human Behavior. ISSN: 0747-5632. Vol. 78, January 2018, pp. 151-159. Publication: 25 September 2017. Retrieved 20.05.2018 from: https://doi.org/10.1016/j. chb.2017.09.032

Bonch-Osmolovskaya T. (2015). Combating the Russian State Propaganda Machine: Strategies of Information Resistance. Journal of Soviet and Post-Soviet Politics and Society. ISSN 2364-5334. Special Issue: Russian Media and the War in Ukraine. Vol. 1, No 1(2015), p. 175. Retrieved 20.05.2018 from: http://spps-jspps.autorenbetreuung.de/files/06-bonch-osmolovskaya.pdf

Buczyński J. (2011). Teoria bezpieczeństwa: procedury i metody badawcze. Przeglad Naukowo-Metodyczny. Edukacja dla Bezpieczeństwa. ISSN 1899-3524. No 2/11/2011, pp. 53-63, p. 59. Retrieved 20.05.2018 from: http://www.przeglad.wsb. net.pl/uploads/1/0/3/7/10371016/2.2011.pdf

Chauvinism. Encyclopeedia Britannica. Retrieved 12.05.2018 from: https://www.britannica.com/topic/chauvinism

Cieślarczyk M. (red.). (2006). Metody, techniki i narzędzia badawcze oraz elementy statystyki stosowane w pracach magisterskich i doktorskich. ISBN: 83-89423-24-3. Warszawa: Akademia Obrony Narodowej, 103 p.

Fedor J. (2015). Introduction: Russian Media and the War in Ukraine. Journal of Soviet and Post-Soviet Politics and Society. ISSN 2364-5334. Special Issue: Russian Media and the War in Ukraine. Vol. 1, No 1(2015). Retrieved 20.05.2018 from: http:// spps-jspps.autorenbetreuung.de/files/00-fedor.pdf

Flejterski S., Solarz J.K. (2015). Komparatystyka finansów. ISBN 978-83-255-6812-2. Warszawa: Wydawnictwo C.H.Beck, 196 s. 
Hural M. (2016). Interpretatsiya kak sposob vossozdaniya khudozhestvennogo perevodnogo teksta. [Interpretation as a Means of Artistic Translatable Text Reproduction]. Materialy XX Vseukrayins'koyi naukovo-praktychnoyi internet-konferentsiyi "Vitchyznyana nauka na zlami epokh: problemy ta perspektyvy rozvytku" [Materials of the XXth Ukrainian scientific-practical conference "Domestic Science: Problems and Development Perspectives on the Fracture of Epochs"]. Collection of Scientific Works, Issue. 20. Pereiaslav-Khmelnytskyi: Pereiaslav-Khmelnytskyi State Pedagogical Gregory Skovoroda University. Retrieved 12.05.2018 from: https://confscience.webnode.com.ua/_files/200000026-5dedd5eee5/\%D0\%97\%D0\%B1\%D1\%96\% D1\%80\%D0\%BD\%D0\%B8\%D0\%BA\%2020.pdf (in Russian).

Jemioło T., Dawidczyk A. (2008). Wprowadzenie do metodologii badań bezpieczeństwa. ISBN 978-83-7523-030-7. Warszawa: Akademia Obrony Narodowej, 85 s.

Jingoism. Encyclopcedia Britannica. Retrieved 12.05.2018 from: https://www.britannica.com/topic/jingoism

Kacała T. (2012). Porównanie jako metoda badawcza w naukach o obronności. in: Obronność - Zeszyty Naukowe Wydziału Zarządzania i Dowodzenia Akademii Obrony Narodowej, ISSN 2084-7297, No 1/2012, pp. 94-109. Retrieved 20.05.2018 from: http://bazhum.muzhp.pl/media//files/Obronnosc_Zeszyty_Naukowe_Wydzialu_Zarzadzania_i_Dowodzenia_Akademii_Obrony_Narodowej/ Obronnosc_Zeszyty_Naukowe_Wydzialu_Zarzadzania_i_Dowodzenia_Akademii_Obrony_Narodowej-r2012-t-n1/Obronnosc_Zeszyty_Naukowe_Wydzialu_ Zarzadzania_i_Dowodzenia_Akademii_Obrony_Narodowej-r2012-t-n1-s94-109/ Obronnosc_Zeszyty_Naukowe_Wydzialu_Zarzadzania_i_Dowodzenia_Akademii_Obrony_Narodowej-r2012-t-n1-s94-109.pdf

Literaturoznavchyy slovnyk-dovidnyk. [Reference Book on Literary Terms]. (2007). (ed. by R.T. Hromiak, Y.I. Kovaliv, V.I. Teremko). ISBN 978-966-580-244-0. Kyiv: PC "Akademia", 752 p. Retrieved 12.05.2018 from: http://shron1.chtyvo.org.ua/ Hromiak_Roman/Literaturoznavchyi_slovnyk-dovidnyk.pdf . (in Ukrainian).

Perespivuvaty. [Providing Free Translation]. (1975). Slovnyk ukrayins'koyi movy: $v 11$ tomakh. [Ukrainian Language Dictionary: in 11 volumes]. Vol. 6. Retrieved 12.05.2018 from: http://sum.in.ua/s/perespivuvaty . (in Ukrainian).

Shevnin O. (2016). Yak perekladachi zbytkuyut'sya nad zirkamy i plekayut' rozzyav. [How Translators Scorn on Stars and Cherish Absentminded People]. Delovaya stolitsa: online gazeta [Business Capital: online newspaper]. Publication: 30.09.2016. Retrieved 12.05.2018 from: http://www.dsnews.ua/society/yak-perekladachi-zbitkuyutsya-nad-zirkami-i-plekayut-rozzyav-30092016193800 . (in Ukrainian).

Sokolova S. (2017). The Russian-language Wikipedia as a Measure of Society Political Mythologization. Journal of Modern Science. ISSN 1734-2031. 
Vol. 2/33/2017, pp. 147-176. Retrieved 20.05.2018 from: http://www.jomswsge. com/The-Russian-language-Wikipedia-nas-a-Measure-of-Society-Political-nMythologization,79740,0,1.html

Such J., Szcześniak M. (2000). Filozofia nauki. ISBN 83-232-0975-8. Poznań: Wydawnictwo naukowe, $120 \mathrm{p}$.

Toftul M. (2014). Shovinizm velykoderzhavnyy. [Great-Power State Chauvinism]. Suchasnyy slovnyk $z$ etyky. [Modern Dictionary on Ethics]. ISBN 978-966-485-156-2. Zhytomyr: Zhytomyr Ivan Franko State University, 416 p. Retrieved 12.05.2018 from: http://eprints.zu.edu.ua/11783/1/\%D0\%B5\%D1\%82\%D0\%B8\%D0\%BAa-1. pdf (in Ukrainian).

Tokarczyk R. (2008). Komparastyka prawnicza. ISBN: 978-83-7601-359-6. Warszawa: Wolters Kluwer, 263 p.

Travestiya. [Travesty]. (1979). Slovnyk ukrayins'koyi movy: v 11 tomakh. [Ukrainian Language Dictionary: in 11 volumes]. Vol. 10. Retrieved 12.05.2018 from: http:// sum.in.ua/s/travestija . (in Ukrainian).

Wager E. (2013). What to do if you suspect plagiarism: (b) Suspected plagiarism in a published manuscript. Committee on Publication Ethics (Official website). Retrieved 12.05.2018 from: https://publicationethics.org/files/plagiarism\%20B.pdf

Yas O. (2013). Shovinizm. [Chauvinism]. Entsyklopediya istoriyi Ukrayiny [Ukrainian History Encyclopedia]. Vol. 10: T-Я. Ed. Board: V.A. Smolii (the head) and others. NAS of Ukraine. The Institute of Ukrainian History. Kyiv: "Naukova Dumka", 688 p. Retrieved 12.05.2018 from: http://www.history.org.ua/?termin=Shovinizm (in Ukrainian).

Zakon Ukrayiny "Pro avtors'ke pravo i sumizhni prava" [Law of Ukraine "On Copyright and Related Rights"] dated 23.12.1993 No 3792-XII in the wording of 26.04.2017. Retrieved 12.05.2018 from: http://zakon3.rada.gov.ua/laws/show/3792-12/page . (in Ukrainian).

Żydok R. (2008). Przedmioty i metody badań politologicznych. Radosław Żydok: blog prywatny. Publication: 22.01.2008. Retrieved 01.12.2017 from: http://www.zydok. com/2008/01/przedmioty-i-metody-badan-politologicznych/

\section{Internet source}

Aleksandr. (2013). Sam fakt sushchestvovaniya... [Existence fact itself...]. Donetsko-Krivorozhskaya respublika: rasstrelyannaya mechta. Blog Vladimira Kornilova. [Donetsk-Krivorog Republic: shot dream. Blog of Vladimir Kornilov]. Publication: 29.07.2013. Retrieved 25.05.2018 from: http://kornilov.name/levyie-dveri-spravaili-samuil-marshak-v-grobu-perevorachivaetsya/\#comment-7467 (in Russian). 
BuhI.(2017).Uti-puti)) gdeukazanochto eto perevod... [Teeny-weeny)) where can one see if it's a translation?...]. Facebook. Publication: 28.11.2017. Retrieved (12.05.2018) from: https://www.facebook.com/GlebUkraine/posts/1102368966566855?comment_id=1102419376561814\&reply_comment_id=1102421579894927\&comment_tracking=\%7B\%22tn\%22\%3A\%22R8\%22\%7D (in Russian).

Dubova A. (2018). Para slov o podache informatsii. [A Couple of Words on the Information Presenting Techniques]. Facebook. Publication: 11.02.2018. Retrieved 08.06.2018 from: https://web.facebook.com/photo.php?fbi$\mathrm{d}=783757661810369 \&$ set $=\mathrm{a} .173829266136548 .1073741826 .100005284263630 \&$ type $=3 \&$ theater (in Russian).

Ivan Malkovych za Samuyilom Marshakom "Otakyy rozzyava”. [Ivan Malkovych after Samuil Marshak "The Absentminded Fellow"]. YouTube. Publication: 30.09.2014. Retrieved 12.05.2018 from: https://www.youtube.com/watch?v=yd7iLspt36k (in Ukrainian).

Kornilov V. (2012). Levyye dveri sprava! Ili Samuil Marshak v grobu perevorachivayetsya. [Left Door to the Right! Or Samuil Marshk is Turning Over in His Tomb]. Donetsko-Krivorozhskaya respublika: rasstrelyannaya mechta. Blog Vladimira Kornilova. [Donetsk-Krivorog Republic: shot dream. Blog of Vladimir Kornilov]. Publication: 25.06.2012. Retrieved (25.05.2018) from: http://kornilov.name/levyie-dveri-sprava-ili-samuil-marshak-v-grobu-perevorachivaetsya/ (in Russian).

Kurnosov S. (2017). Skuchno s vami... [It's too boring to stay with you]. Facebook. Publication: 28.11.2017. Retrieved 12.05.2018 from: https://www.facebook.com/ GlebUkraine/posts/1102368966566855?comment_id=1102419376561814\&reply_comment_id=1102424839894601\&comment_tracking=\%7B\%22tn\%22\%3A\%22R0\%22\%7D (in Russian).

Kvach Y. (2013). Propahanda rosiys'koho natsionalizmu v Odesi, Ukrayina. Napys na posteri [Russian Nationalism propaganda in Odesa, Ukraine. The writing on the poster]. Wikimedia Commons. Publication: 18.06.2013. Retrieved 09.06.2018 from: https://commons.wikimedia.org/wiki/File:Russian_Nationalism.jpg (in Russian).

Lukanov Y. (2017). Meni duzhe podobayet'sya... [I like it so much...]. Facebook. Publication: 30.11.2017. Retrieved 12.05.2018 from: https://web.facebook.com/yuriy. lukanov/posts/10155906216474304 (in Ukrainian).

Lyashenko G. (2017). Venets patrioticheskogo marazma. [The peak of patriotic decrepitude]. Facebook. Publication: 28.11.2017. Retrieved 12.05.2018 from: https:// web.facebook.com/photo.php?fbid=1102364789900606\&set=a.254050994731994. 1073741828.100003812878330\&type $=3 \&$ theater (in Russian). 
Malkovych I. Otakyy rozzyava (Perespiv z rosiys'koyi). [The Absentminded Fellow (free translation from Russian)]. Ukrayins'ka literatura: elektronna biblioteka. [Ukrainian literature: electronic library]. Retrieved 12.05.2018 from: http://ukrclassic.com.ua/katalog/m/malkovich-ivan/1508-ivan-malkovich-otakij-rozzyava (in Ukrainian).

Marshak S. Shaltay-boltay. [Humpty Dumpty]. World Art. Retrieved 12.05.2018 from: http://www.world-art.ru/lyric/lyric.php?id=4371 (in Russian).

Marshak S. Vot kakoy rasseyannyy. [The Absentminded Fellow]. Chudesnaya strana: detskiy sayt dlya roditeley. [Wonderful Land: children's website for Adults]. Retrieved 12.05.2018 from: http://www.chudesnayastrana.ru/samuil-marshak.htm (in Russian).

Na Ukraine Pushkina i Bulgakova nazvali plagiatorami. [Pushkin and Bulgakov have been called plagiarists in Ukraine]. (2018). Stuki-Druki. Publication: 29.01.2018. Retrieved 10.06.2018 from: http://stuki-druki.com/marazm1/Na-Ukraine-Pushkina-i-Bulgakova-nazvali-plagiatorami.php (in Russian).

Vladislav. (2012). S samoy postanovki voprosa... [From the very formulation of the question]. Donetsko-Krivorozhskaya respublika: rasstrelyannaya mechta. Blog Vladimira Kornilova. [Donetsk-Krivorog Republic: shot dream. Blog of Vladimir Kornilov]. Publication: 27.06.2012. Retrieved 25.05.2018 from: http://kornilov.name/ levyie-dveri-sprava-ili-samuil-marshak-v-grobu-perevorachivaetsya/\#comment3616 (in Russian).

Vynnychuk Y. (2018). Ne nam, bl@dyam. [It’s not we the D@mn who mean].ZBRUČ. Publication: 28.01.2018. Retrieved 12.05.2018 from: https://zbruc.eu/node/75924 (in Ukrainian).

Yaskov V. (2017). Vy napysaly... [You wrote...]. Facebook. Publication: 30.11.2017. Retrieved 12.05.2018 from: https://web.facebook.com/yuriy.lukanov/posts/10155906216474304 (in Ukrainian). 
